\author{
Mehmet Akif Ersoy Üniversitesi Fen Bilimleri Enstitüsü Dergisi 12(1): 76-91 (2021) \\ The Journal of Graduate School of Natural and Applied Sciences of Mehmet Akif Ersoy University 12(1): 76-91 (2021)
}

Araştırma Makalesi / Research Paper

\title{
Kent Parkına Yönelik Kurakçıl Peyzaj Tasarım Önerisi: Antalya Serdengeçti Parkı
}

\author{
Ceren SELIM iD 1*, Gülşah BAYRAK ${ }^{\mathbb{D} 2}$, Sema DOKSÖZ ${ }^{\mathbb{D} 2}$ \\ ${ }^{1}$ Akdeniz Üniversitesi, Mimarlık Fakültesi, Antalya \\ ${ }^{2}$ Akdeniz Üniversitesi, Fen Bilimleri Enstitüsü, Antalya \\ Geliş Tarihi (Received): 19.02.2021, Kabul Tarihi (Accepted): 21.03.2021 \\ $\square$ Sorumlu Yazar (Corresponding author*): cerenselim@akdeniz.edu.tr \\ (C) +902423104453 등 +902423102258
}

ÖZ

Kullanılabilir su varlığının azalması sonucu arazide su verimliliği de giderek artan bir sorun haline gelmektedir. Son on yılda su kullanımına ilişkin farkındalık artmış olsa da yeşil alanların sulanması hala su tüketiminin büyük bir yüzdesini oluşturmaktadır. Bu nedenle arazide su kullanımının azaltılması, su kaynaklarının korunması için hayati bir adımdır. Artık yoğun sulama gerektiren klasik peyzaj anlayışından vazgeçilerek, suyu etkin kullanımını sağlanmasını öneren "Kurakçıl Peyzaj" (Xeriscape) gibi peyzaj yaklaşımlarına gereksinim duyulmaktadır. Kurakçıl peyzaj tasarımı su ve enerjiyi etkili kullanan yaratıcı peyzajlar oluşturarak ekolojik, ekonomik ve estetik birçok fayda sağlamayı hedefleyen bir tasarım yaklaşımıdır. Bu çalışmada Antalya ili Muratpaşa ilçesinde kent halkı tarafından oldukça yoğun kullanılan bir bölgede yer alan Serdengeçti Parkı, su etkin peyzajlar yaratan xeriscape yaklaşımını tanıtmak ve bir cazibe merkezi oluşturmak amacıyla kurakçıl peyzaj tasarım yaklaşımı ile tasarım önerisi geliştirilmiştir.

Anahtar Kelimeler: Antalya, ekolojik tasarım, kurakçıl peyzaj tasarımı, su etkin peyzaj

\section{Xeriscape Design Proposal for the City Park: Antalya Serdengeçti Park, Turkey}

\begin{abstract}
Today, as a result of the decrease in water, water efficiency in the field is becoming an increasing problem. Although awareness of water use has increased in the last decade, irrigation of green spaces still accounts for a large percentage of water consumption. For this reason, reducing water use on land is a vital step in protecting water resources. Landscape approaches such as "Xeriscape", which use water efficiently, are now needed by abandoning the classical landscape approach that requires intense irrigation. Xeriscape design is an approach that aims to provide many ecological, economic and aesthetic benefits by creating creative landscapes that use water and energy effectively. In this study, Serdengeçti Park which is located in an area heavily used by the city people in Muratpaşa district of Antalya province, has been redesigned with xeriscape approach that creates water efficient landscapes and a center of attraction.
\end{abstract}

Keywords: Antalya, ecological design, xeriscape landscape design, water efficient landscape

\section{GíRiş}

Kent, sürekli toplumsal gelişme içinde bulunan ve toplumun, yerleşme, barınma, ulaşım, çalışma, dinlenme, eğlenme gibi gereksinmelerinin karşılandığı, pek az kimsenin tarımsal uğraşlarda bulunduğu, kırsal peyzaja göre nüfus yönünden daha yoğun olan yerleşme birimi olarak tanımlanmaktadır (Keleş, 1998). 
Sürdürülebilir kent kavramının gündeme gelmesinden sonra, çevre duyarlı kentsel gelişmeyi sağlayabilmek için, kentsel mekânların ekolojik planlama anlayışıyla planlanması gerektiği ortaya çıkmıştır. Bu bağlamda, peyzaj tasarımlarında ekolojik yaklaşımlar da giderek önem kazanmaya başlamıştır. Yeşil altyapı, yeşil yol, ekolojik ağ, yeşil kama vb. sistemleri bu yönde yapılan çalışmalardan bazılarıdır. Aynı zamanda Eroğlu ve Acar (2016)'ın da bahsettiği gibi bu tür yaklaşımlarla kent içerisinde yer alan kent parkı, oyun parkı, spor alanı vb. farklı nitelikteki açık ve yeşil alanlara kent bütünü içerisinde birtakım çözüm önerileri getirilmektedir (Korkut ve ark., 2017).

McHarg (1969)'tan geliştirilen ekolojik tasarım yaklaşımına ilişkin temel ilkeler şu şekilde sıralanabilir; mevcut peyzaj karakterinin korunması, geliştirilen tasarımların ekolojik koşullara ve iklimsel verilere uygun olması, tasarımda yerel kaynakların kullanımı, kentsel peyzaj tasarımda ekolojik yaklaşımlar, su etkin peyzaj tasarımı (water-efficient landscaping), kurakçıl peyzaj (xeriscape) düzenleme, enerji etkin peyzaj tasarımı (energy-efficient landscaping), sürdürülebilir tarım (permaculture), yenilenebilir enerji kaynaklarının kullanımı, yeşil çatı (greenroof) ve yeşil duvar (greenwall) uygulamaları, alternatif yeşil alanların oluşturulması şeklinde sıralanabilir (Aklanoğlu, 2009; Korkut ve ark., 2017).

Kentsel peyzaj tasarımda ekolojik yaklaşımlar arasında yer alan Xeriscape (Kurakçıl peyzaj) terimi Yunanca kurak anlamına gelen "Xeros" ve İngilizce'de peyzaj anlamına gelen "Landscape" kelimelerinden türetilmiştir (Wilson ve Feucht, 2007) Bu kavram ilk kez ilk kez 1978 yılında ABD'nin Denver eyaleti Colorado kentinde Denver Su Departmanı ve Colorado Devlet Üniversitesi tarafından, peyzaj düzenlemelerinde suyun tasarrufu ve korunumu amaçlı geliştirilmiştir. Bu yaklaşım kapsamında ilk bahçe 1980'li yıllarda Colorado'da kurulmuştur. Kurakçıl peyzajın tüm özelliklerini içeren "Xeriscape Demonstration Garden" (Kurakçıl peyzaj tanıtım bahçesi) ise ilk bahçenin devamı niteliğinde varlığını günümüzde de sürdürmektedir (Şahin, 2013).

Çorbacı ve ark. (2011) Xeriscape kavramını su ve enerjiyi etkili kullanan yaratıcı peyzaj çalışmaları ve çevreyi koruyan ve su tüketimini minimuma indiren kaliteli peyzaj yaratma tekniği olarak tanımlamıştır. Bu şekilde su tüketimi minimuma indirmek hedeflenerek peyzaj projelerinin tasarlanmasını amaçlar. Bu yaklaşım kentsel peyzaja su tasarrufu ve bakım masraflarını azaltma yanında daha pek çok fayda sunmaktadır. Welsh (2000)'e göre kurakçıl peyzajın yararları su tasarrufu sağlaması, peyzaj uygulamasının kuraklıktan ve su kıtlığından kaynaklanabilecek zararlara karşı daha dayanıklı hale getirmesi ve ekolojik olarak daha uygun çözümlere üreterek yüksek kaliteli peyzajlar oluşturması şeklinde sıralamıştır. Tüm faydalar bir arada düşünüldüğünde; ekolojik (su tasarrufu, su kaynaklarına katkı, bitkiler ve yaban hayatı için habitat, biyolojik çeşitliliğin korunması, toprağı iyileştirme, erozyonu önleme, kimyasal kullanımını azaltma, yeraltı sularının kirlenmesini önleme), estetik (görsel çevre kalitesini artırma, odak noktası oluşturma, tasarımda çeşitlilik sağlama) ve ekonomik (bakım maliyetini azaltma, enerji tasarrufu sağlama, işçilik giderlerini azaltma, emek tasarrufu, su faturasını düşürme, zaman tasarrufu) olarak tanımlanabilmektedir (Birişçi ve ark., 2017). Kurakçıl peyzaj, yenilikçi su koruma tekniklerini sağlıkı bahçecilik uygulamaları ile birleştiren yedi temel prensibi içeren bir tasarım yaklaşımıdır. Su korumanın yanında sadece renkli ve güzel bir peyzaj yaratmakla kalmaz, aynı zamanda zamandan, enerjiden ve paradan tasarruf ederek daha sürdürülebilir peyzajlar yaratmayı amaçlamaktadır (Detweiler ve ark., 2005; Welsh ve Welch, 2007). Bu yedi temel prensip (Welsh ve Welch, 2007):

- Uygun planlama ve tasarım

- Toprak ıslahı

- Uygun bitki seçimi

- Sürdürülebilir çim alanlar

- Etkin sulama

- Malç kullanımı

- Uygun ve sürdürülebilir bakım faaliyetleridir.

\section{Uygun Planlama ve Tasarım}

Suyu verimli kullanan bir peyzaj oluşturmak, iyi düşünülmüş bir planlama ve tasarım ile başlar. Bunun için öncelikle mevcut durumun ve çevresel kullanımların belirlenmesi, alanda var olan yapısal ve bitkisel materyalin tespiti, gölgelenme durumları, alandan beklentiler bir plan üzerinde belirlenmelidir. Bu aşamada kurakçıl peyzaj yaklaşımıyla tasarlanacak yerde alan kullanımlarının belirlenmesi, su kullanım zonlarının oluşturulması, bitkilerin uygun yere yerleştirilmesi ve ekolojik istekleri benzer ya da aynı bitkilerin gruplar halinde kullanılması için planlama yapılması, mevcut suyun korunmasını sağlayan planlama ve tasarım stratejilerini içermektedir.

\section{Toprak Analizi ve Hazırlığı}

Toprak yapısının bilinmesi başarılı bir kurakçıl peyzaj uygulaması için oldukça önemlidir. Her toprağın kendine özgü tekstürü, drenaj düzeni, $p H^{\prime} ı$, besin içeriği bulunmaktadır. Bu bilginin toprak analizi ile elde edil- 
mesi gerekmektedir (Wade ve ark., 2007). Toprak analiz raporuna göre gerekli görülen gübre ve organik madde takviyesi yapılması uygun bir uygulamadır. Toprağa bir miktar organik madde eklenmesi toprağın su tutma kapasitesini arttıracaktır. Genel bir kural olarak, çam kabuğu, kompost veya yapraklar gibi organik malzemelerin toprağın ilk 10-15 cm lik kısmına karıştırılması suyun etkin kullanımını sağlanmasına yardımcı olacaktır (Welsh ve Welch, 2007).

\section{Uygun Bitki Seçimi}

Uygun bitki seçimi, sadece tasarımla uyumlu değil, aynı zamanda toprağa ve yerel iklime de çok uygun bitkilerin seçilmesi anlamına gelmektedir. Bitkilerin toprak tipine ve alanın güneşlenme süresine göre seçilmesini gerektirmektedir. İdeal olarak, seçilen bitkiler, sıcaklık ve toprak nemindeki yerel dalgalanmalara uyum sağlayabilecek şekilde seçilmelidir. Kuraklık ve yörenin diğer ekstrem koşullarına tolerans, kurakçıl peyzaj tasarım yaklaşımında önemli bir kavramdır (Wade ve ark., 2007). Bu kapsamda doğal türlerin ve yöreye iyi adaptasyon sağlayabilmiş egzotik türlerin kullanımının tercihi ön plana çıkmaktadır. Daha az sulama, gübreleme ve bakım gerektiren bu türlerin kullanımı ile sürdürülebilir peyzajlar yaratılmasına katkı sağlamaktadır (Metin ve Koçan, 2020). Seçilen bitkilerin sağlıklı olması, su gereksinimlerinin belirlenmesi ve benzer su tüketimine sahip bitkilerin bir arada kullanımının sağlanması sulamanın etkin yapılabilmesi açısından göz önünde bulundurulması gereken bir diğer konudur.

\section{Sürdürülebilir Çim Alanlar}

Çim bitkileri, bitkisel tasarımlarda kullanılan birçok bitkiye kıyasla daha fazla suya ve bakıma intiyaç duyan bitkilerdir. Su kaynakları üzerindeki baskının azaltılmasında çim alanların gerekliliği sorgulanmalıdır. Eğer çim alan gerekli ise tercih edilmeli, farklı türler ile çözüm üretilebiliyor ise çim alan yerine bitki parterleri, yer örtücüler ile çözüm bulunması önerilmektedir. Seçilen çim türünün mevcut ekolojik koşullara, iklim ve toprak yapısına uygun, az su tüketen tür ve çeşitliler seçilerek tesis edilmesi önem taşımaktadır. Ayrıca çim alanların sulanmasının kolaylığı da göz önünde bulundurularak, bakımı daha kolay olacak şekilde mümkün olduğunca devamlıı̆ın sağlandığı tek parça alanlar şeklinde tesis edilmesi önerilmektedir (Welch ve ark., 2007).

\section{Etkin Sulama}

Sulama, bitkilerin intiyaç duyduğu ancak doğal yağışlarla karşılanamayan suyun yapay olarak getirilmesi iş- lemidir. Başka bir tanımla, sulama; kontrollü miktarlarda suyun bitkilere gerekli aralıklarla uygulanmasıdır. Peyzajlarda etkin ve iyi planlanmış sulama sistemlerinin kullanımı ile su kaynaklarının üzerindeki baskı ortadan kaldırılırken zamandan ve paradan da tasarruf sağlanabilir. Fazla sulama su israfına neden olmakla birlikte besinleri bitki köklerinden uzaklaşarak yıkanmasına sebep olmaktadır. Ayrıca gübre ve ilaçların yer altı sularına karışarak kirlenmesine sebep olabilmektedir. Bu sorunlar uygun sulama tekniklerinin belirlenmesi ve bir arada kullanımı ile ortadan kaldırılabilir (Welch ve ark., 2007). Yapılan çalışmalar otomatik sulama sistemlerinin manuel sulamaya göre \%30 daha verimli olduğunu ortaya koymuştur (Detweiler ve ark., 2005). Kurakçıl peyzaj yaklaşımı ile tasarlanacak bir alanda çim alanlarda yağmurlama, çalı, ağaç ve mevsimliklerde kök izdüşümlerine su damlatmak suretiyle damlama ve mikro-sprey sulama sistemlerinin entegre kullanımı şeklinde uygun bir otomatik sistem tercih edilmesi önerilmektedir.

\section{Malç Kullanımı}

Ağaç, çalı ve mevsimlik çiçeklerin kök tacını örtmek için kullanılan organik ya da inorganik kökenli malzemelere malç denilmektedir. Yabani otların topraktan çıkışının engellenmesi, toprak neminin ve ısısının optimumda tutulması, toprak erozyonunun engellenmesi, toprak yapısının iyileştirilmesi, tasarıma estetik katkıları malçın bilinen faydaları arasındadır. Kurakçıl peyzaj yaklaşımında malçın bahsedilen faydalarından yararlanılarak kullanımına sıklıkla yer verilmektedir.

\section{Uygun ve Sürdürülebilir Bakım Faaliyetleri}

Kurakçıl peyzaj tasarım yaklaşımı temel prensiplerinin uygulanması çevrenin güzelliğinden ödün vermeden sadece su, para ve zamandan tasarrufu sağlamakla kalmayıp aynı zamanda minimum bakım gerektiren, akıllıca tasarlanan peyzajlar oluşturulmasını sağlamaktadır. Bu yaklaşımda bitkilerin sürekli ve sınırsız büyümesinin sağlanması değil sağlıklı kalmasının sağlanması teşvik edilmektedir. Mevcut bakım düzeyine bağlı olarak, daha az gübreleme yapılmasını, yalnızca gerekli olduğunda hafif budama yapılmasını ve daha az sulama yapılmasını gerektirir.

Bu çalışmanın amacı, Antalya ili Muratpaşa ilçesinde bulunan Serdengeçti parkının kurakçıl peyzaj (Xeriscape) tasarım yaklaşımıyla yeniden tasarlanması ve kent halkı tarafından oldukça yoğun kullanımda olan bir bölgede bu tasarım ile su etkin peyzajlar ve kurakçıl peyzaj yaklaşımı hakkında bilinç seviyesini arttırılması amaçlanmıştır. 


\section{MATERYAL VE YÖNTEM}

\section{Materyal}

Çalışma alanının ana materyalini Antalya ili Muratpaşa ilçesinde bulunan Serdengeçti parkı oluşturmaktadır (Şekil 1). Park, 2004-2014 yılları arasında çeşitli sebeplerle yıkılamayan, ardından yasal süreçlerin tamamlanmasıyla parktaki il özel idare binasının yıkılması sonrasında 2015 yılında "Çocuk ve Çiçek" konseptiyle park olarak tasarlanmıştır.

5,6 da büyüklüğündeki park, Antalya kent merkezinde bulunmakta olup Cumhuriyet meydanına $350 \mathrm{~m}$ yürüme mesafesinde, Kaleiçi yat limanına 400 m yürüme mesafesindedir. Alana en yakın otobüs durağı $380 \mathrm{~m}$ mesafe uzağında bulunmaktadır (Şekil 2). Çalışma alanının güneyinde denize paralel olarak araç ve tramvay yolu, kuzeyinden ise bisiklet yolu geçmektedir. Alana en yakın parklar Yavuz Özcan parkı ve Atatürk parkıdır. Alan ulaşım kolay ve erişilebilir bir konumda olmasından dolayı kullanıcıların yoğun olarak bulunduğu, oldukça kalabalık bir bölgededir.

Kent halkının su etkin peyzajlar ve kurakçıl peyzaj yaklaşımı hakkında bilinç seviyesini arttırılması amacıyla parkın, bu şekilde kent halkı tarafından oldukça yoğun kullanımda olan bir bölgede seçilmesi istenmiştir.
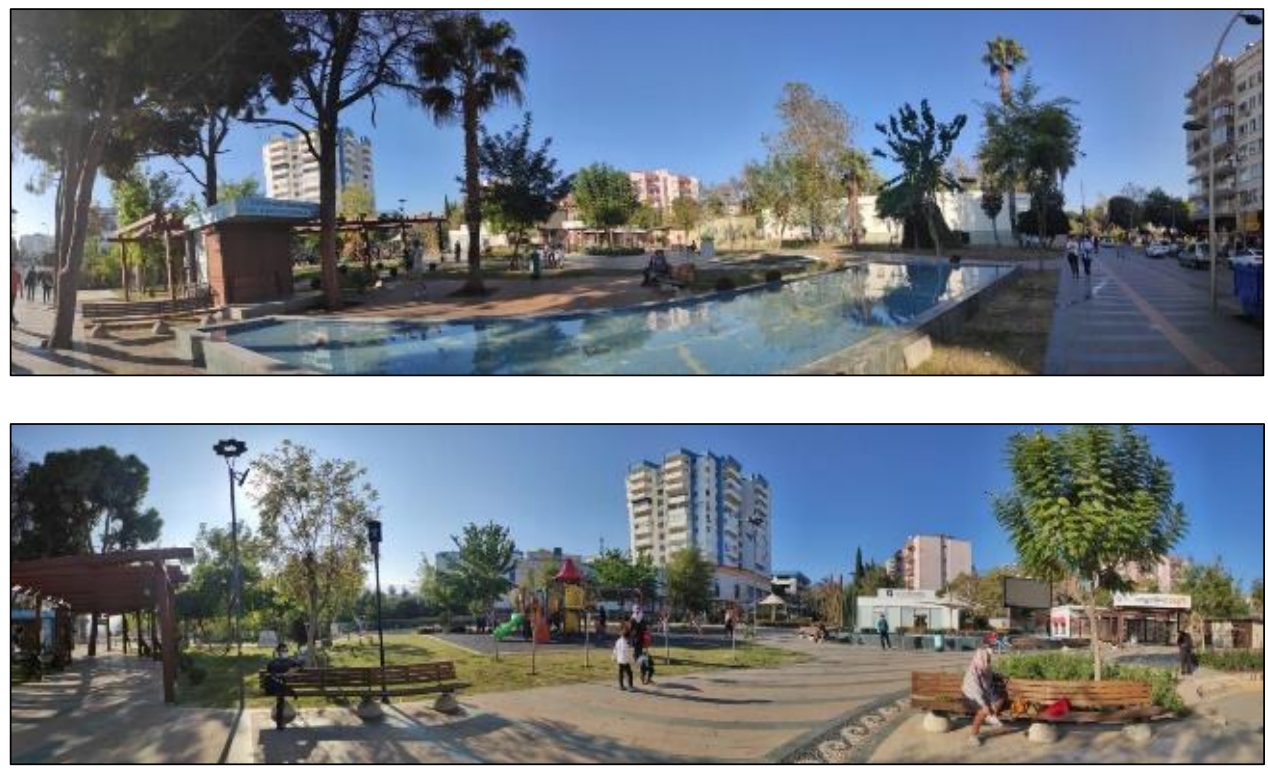

Şekil 1. Serdengeçti parkı

\section{Yöntem}

Çalışma üç aşamada gerçekleşmiştir. İlk aşamada mevcut durum çevre analizi yapılmış olup çalışma alanının sınırları, mevcut yapılar, çevresel kullanımlar, güneşlenme yönü, gölgeli-nemli alanlar ve güneşli-kurak alanlar, mevcut bitkiler belirlenmiştir.

İkinci aşamada kurakçıl peyzaja dair literatürler taranmış, örnek çalışmalar incelenmiştir. Daha sonra çalışmana ait leke çalışması yapılmıştır. Leke çalışmasında kullanım alanları ile ana ve ara akslar belirlenmiş ve kullanılacak bitki türlerinin ekolojik isteklerine göre doğru konumlandırma yapılması amaçlanmıştır. Bu doğrultuda kurakçıl peyzaj yaklaşımının ana ilkelerinden biri olan az su isteyen bitkiler sıcak ve kuru yani güney ve batı bakılı alanlarda, çok su isteyen bitkiler alanın kuzey ve doğu bakılı alanlarında, orta su isteyen bitkiler ise güney ve batı bölge ile kuzey ve doğu bölgelerin kesişim bölgelerinde konumlandırılması hedeflenmiştir.

Üçüncü aşamada ise hazırlanan leke çalışmasından yola çıkarak Avan proje tasarlanmıştır. Fonksiyonel alanların tasarımı, yapısal malzemeler, alanda korunacak bitkilerin varlığı karar verilmiştir. Avan proje sonrasında alan ekolojik istekleri açısından kanaatkâr bitkiler ile alanda oluşturulan zonlar göz önünde bulundurularak bitkisel tasarım paftası tamamlanmıştır. Bitkisel tasarım sonrasında yapısal malzemelere karar verilerek kesin plan oluşturulmuş, bu plan üzerinden yazılımlar kullanılarak üç boyutlu görselleştirmeler yapılmıştır. Kesit ve detay paftaları oluşturulmuştur. 


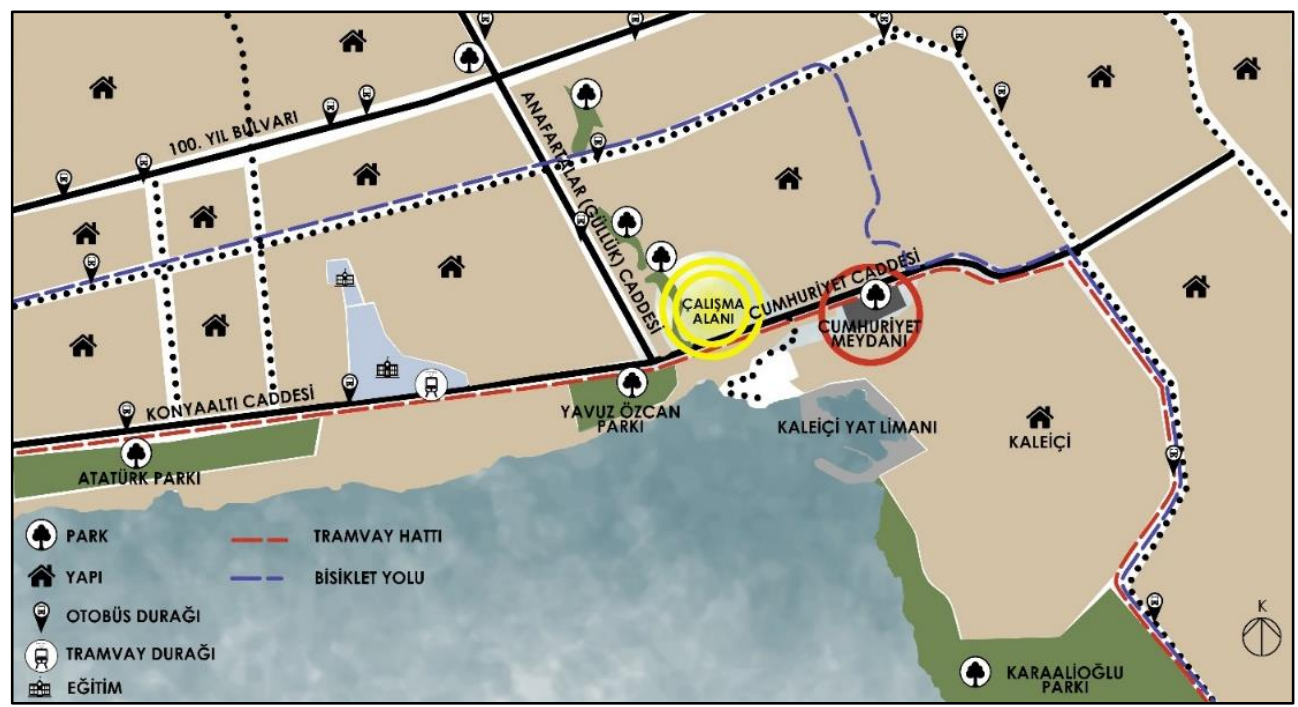

Şekil 2. Serdengeçti parkı konumu ve çevresel bağlantılılık analizi

\section{ARAŞTIRMA BULGULARI}

\section{Serdengeçti Parkı Mevcut Durum Analizi}

Çalışma alanında 2 adet süs havuzu, çocuk oyun alanı, kafe, mini amfi, oturma alanları, el sanatları uygulama ve satış merkezi, el emeği satış merkezi, WC ve trafo binası bulunmaktadır. Mevcutta bulunan bitkiler; Juniperus dru- pacea, Lagerstroemia indica, Laurus nobilis, Olea europaea, Citrus lemon, Acacia sp., Bauhinia variegata, Pinus sp., Ficus benjamina, Buxus sempervirens, Platanus orientalis, Jacaranda mimosifolia, Nandina domestica, Erythrina crista-galli, Cineraria Maritima, Iresine herbstii, Washingtonia sp., Rosa sp. ve mevsimlik çiçek parterleridir (Şekil 3).

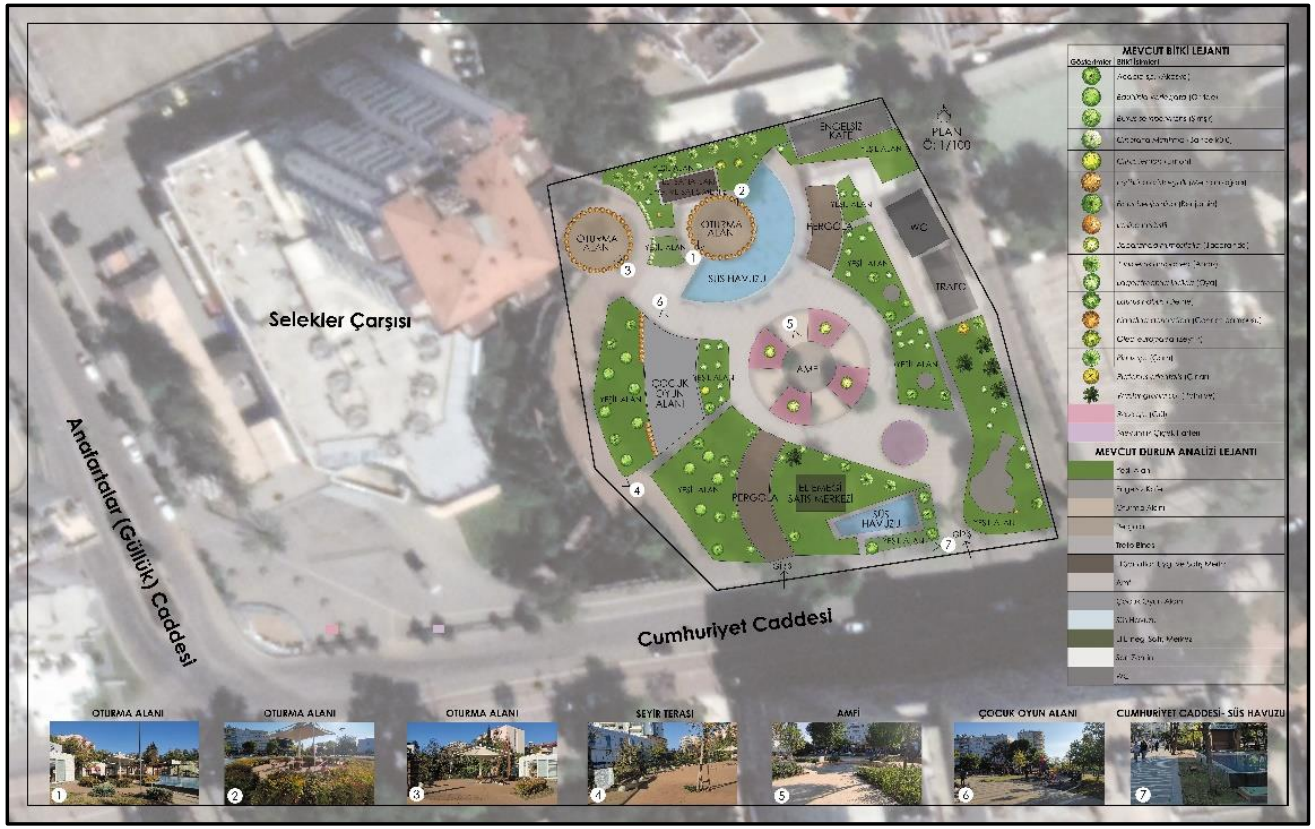

Şekil 3. Serdengeçti parkı mevcut durum analizi 


\section{Tasarım Önerisi I: Kuralsız Park}

$\mathrm{Bu}$ peyzaj tasarım projesinde Serdengeçti Parkına ismini veren ünlü siyasetçi Osman Yüksel Serdengeçti'den esinlenilmiş ve kişiliği tasarımda daha çok hissettirilmesine çalışılmıştır. Bu nedenle ülkemizin ve Antalya'nın siyasi tarihinde önemli bir yere sahip, ülkesi için hiç kimseden korkmadan hareket etmesi, hazır cevaplı olması ve asi ruhuyla tanınmış olan Serdengeçti Osman'ın inişli çıkışlı hayatı, bir kalıba sığmayan asi ruh hali projenin konsepti olarak seçilmiştir. Gerçekleştirilen tasarımda çocukların sadece oyun alanında değil meydanda tasarlanan amorf yapılı oturma birimlerinde, kuru havuzda ve böylelikle parkın birçok yerinde özgürce oynayabilmelerine imkân sağlanmıştır.

\section{Leke Çalışması}

Çalışma alanında mevcutta bulunan süs havuzlarının, el sanatları uygulama ve satış merkezinin, el emeği satış merkezinin ve amfinin kaldırılmasına karar verilmiştir. Amfinin yerine girişte oturma alanları ve kuru havuzları olan bir meydan tasarlanmasına karar verilmiştir. Kafe, WC ve trafo binalarının kalmasına karar verilmiştir. Çocuk oyun alanının aynı yerde fakat yeniden tasarlanmasına karar verilmiştir. Çocuk oyun alanı yanına, girişte ve kafe önünde oturma alanlarına yer verilmiştir. Ara ve ana akslar belirlendikten sonra alanın kuzey, güney, doğu ve batı bölgelerine göre kurakçıl peyzaj tasarım anlayışı ile bitkisel tasarım kararları alınmıştır. Bunlar az su isteyen bitkiler sıcak ve kuru yani güney ve batı bakılı alanlarda, çok su isteyen bitkiler alanın kuzey ve doğu bakılı alanlarında, orta su isteyen bitkiler ise güney ve batı bölge ile kuzey ve doğu bölgelerin kesişim bölgelerinde konumlandırılmıştır (Şekil 4).

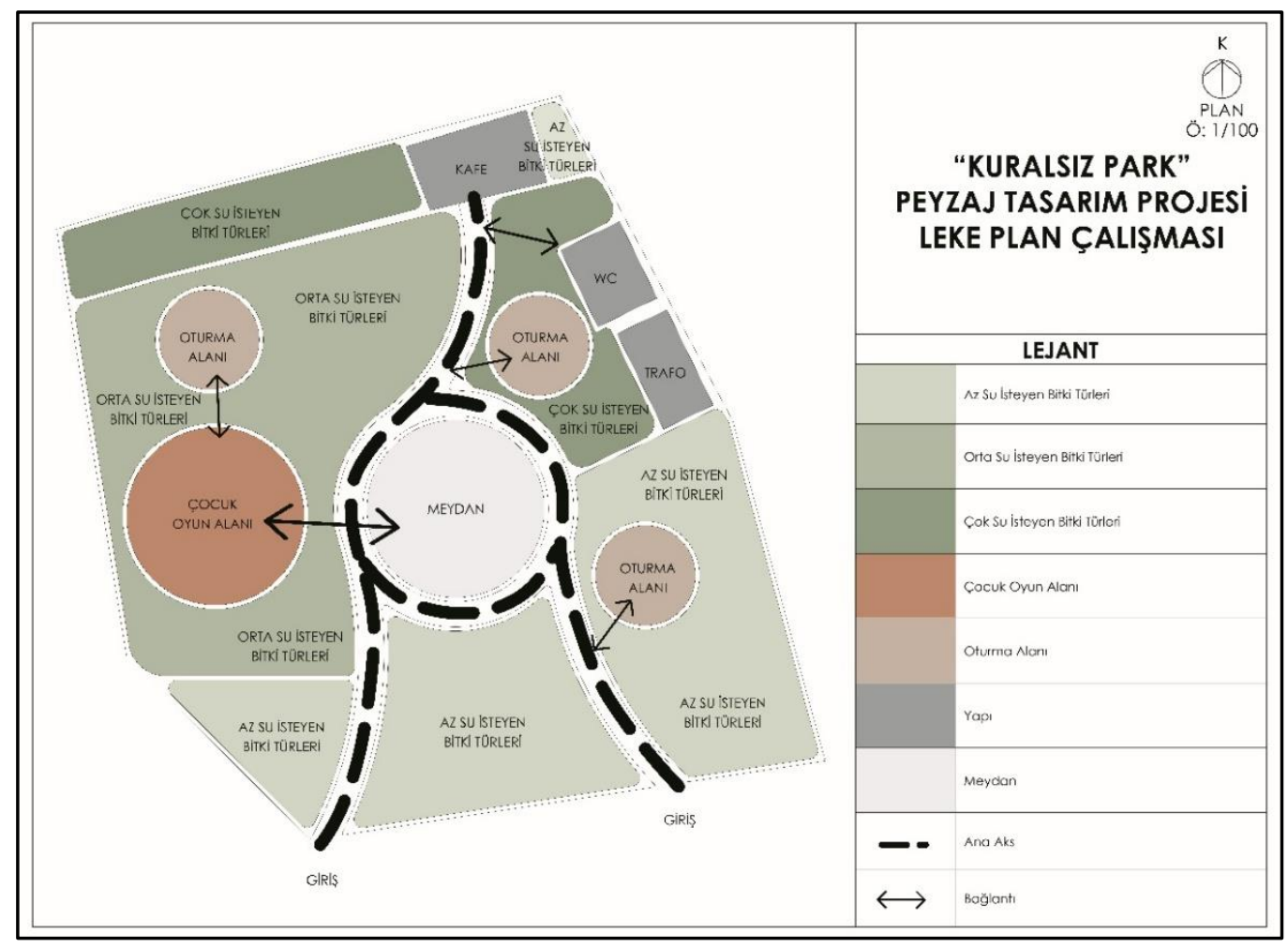

Şekil 4. Leke çalışması

\section{Kesin Plan}

Peyzaj tasarımının form aşamasında Serdengeçti Osman'ın inişli çıkışlı hayatı, bir kalıba sığmayan asi ruh hali konsept alınarak çizgilerle anlatılmaya çalışılmıştır. Alanın merkezinde yer alan meydanda yay şeklinde pergolalar altında güneşten korunarak dinlenme imkânı sağlanmıştır. Meydanın belirli noktalarında tasarlanan kuru havuzlar ile Antalya'nın sıcak havalarına karşı serinletme imkânı sağlamaktadır. Amorf yapılı oturma birimleri kullanıcılara dinlenme haricinde çocuklara zıplama, koşma gibi aktivitelerini gerçekleştirme imkânı sunmaktadır. Ayrıca çocuk oyun alanı için klasik oyun aletleri haricinde tasarlanan tırmanma elemanının çocuklara motor kabiliyeti kazandırması amaçlanmıştır (Şekil 5). 
Mevcut bitkilerden yeni tasarımın formuna ve kurakçıl peyzaj anlayışına uygun olan türlerden birkaçının korunmasına karar verilip leke çalışmasında verilen kararlar doğrultusunda bitkisel tasarım hazırlanmıştır.

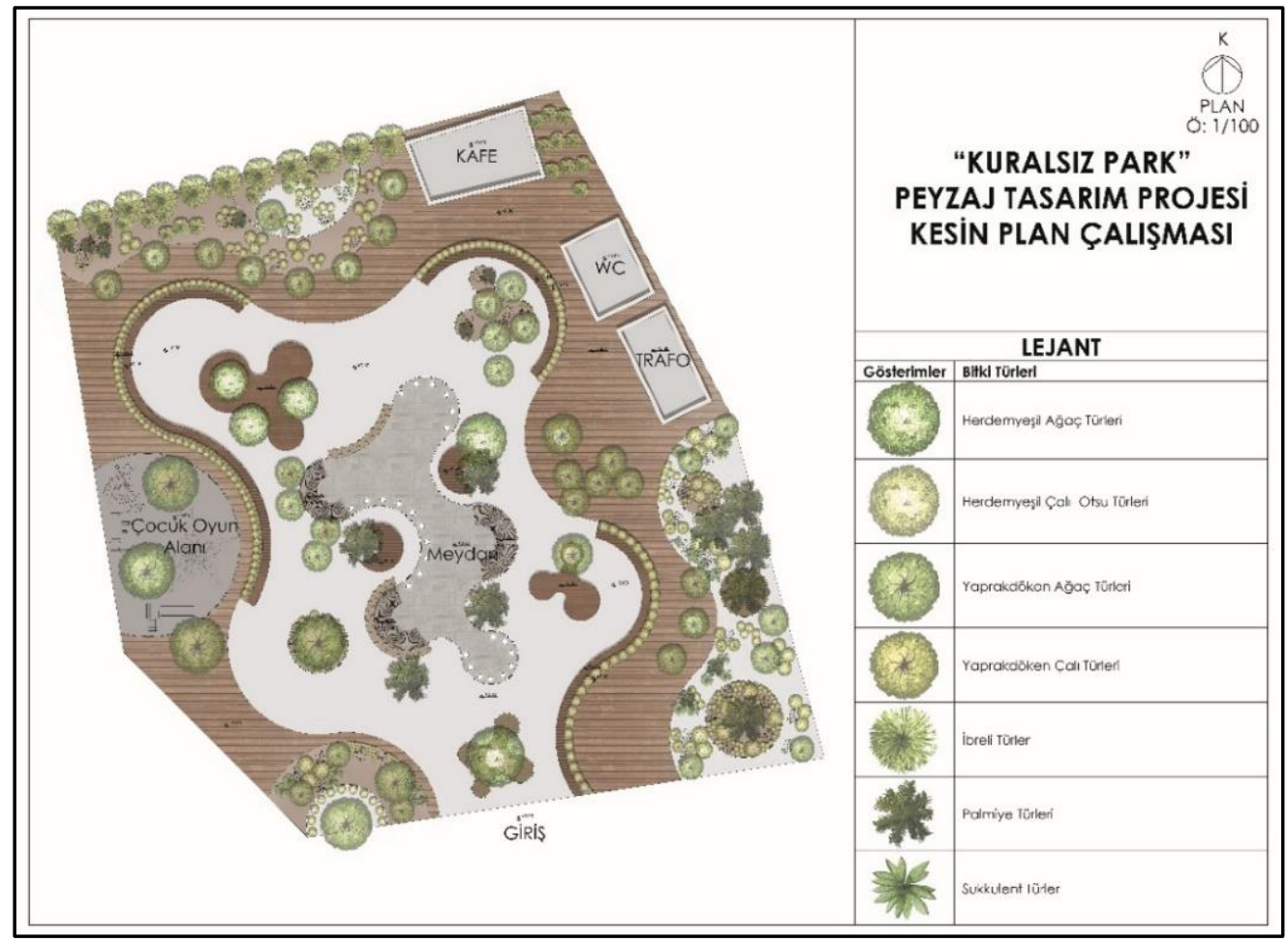

Şekil 5. Kesin plan çalışması

Bitkisel tasarım tasarlanırken kurakçıl peyzaj ilkelerinden uygun bitki seçimi ilkesi doğrultusunda Antalya'nın doğal bitki örtüsüne ait ve ekolojik koşullarına uygun bitki türleri seçilmiştir. Güneyde ve doğuda daha kurakçıl bitkiler ile kuzeyde ve batıda daha çok nemi seven bitki türleri kullanılmıştır. Kuzeyde bulunan bölümde nemi seven bitki türlerinden Cycas revoluta, Carex oshimensis 'Evergold', Miscanthus sinensis 'Flamingo', Agapanthus orientalis, Cyperus alternifolius L., Casuarina aquisetifolia, Iris germanica L. bitkileri doğal taşlarla birlikte kompozisyon yapılmış, bitkilerin altında doğal çam kabuğu ve dolomit taşları malç olarak kullanılmış, mevcutta bulunan Juniperus drupacea korunmuştur. Önündeki ahşap zeminli yol üzerinde Lagerstromia indica yol ağaçlandırması olarak yukardan dallanması nedeniyle tijli formu kullanılmıştır.

Kafenin, yanındaki Juniperus drupacea bitkisi korunmuştur. Önündeki yay şeklinde tasarlanan ahşap kaplama saksıda doğal türler arasında yer alan, kuraklığa dayanıklı ve ek bakıma intiyaç duymayan aromatik yapraklı Salvia officinalis kullanılmıştır. Oturma biriminin önündeki mevcutta bulunan Lagerstromia indica bitkisi yukardan dallanması nedeniyle altına doğal çam kabuğu malcı kullanılarak korunmuştur. Lagerstromia indica'nın altına Cycas revoluta, Carex oshimensis 'Evergold', ve Iris germanica L. bitkileri doğal taşlar ile kompozisyon yapılmıştır (Şekil 6a).

Çocuk oyun alanında mevcutta bulunan Bauhinia variegata alana gölge sağladığı ve Akdeniz iklim koşullarına uyum sağladığı için korunmuştur (Şekil 6b). Önündeki 'S' şeklinde tasarlanan ahşap kaplama saksıda doğal türler arasında yer alan, kuraklığa dayanıklı ve ek bakıma ihtiyaç duymayan aromatik Myrtus communis ile kurak koşullara ve güneşe toleranslı, düzenli bakım gerektirmeyen kaya bahçesinde veya sınırlayıcı bitki olarak kullanılan, dikkat çekici sarı çiçeklere ve forma sahip Santolina chamaecyparissus L. kullanılmıştır. Önündeki amorf yapılı oturma birimi üzerinde ve yanında doğal türler arasında yer alan Laurus nobilis bitkisinin tijli formu kullanıımıştır. 


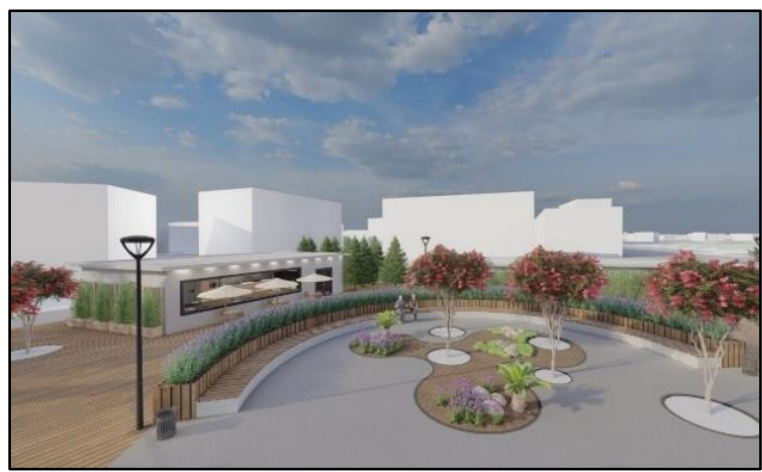

(a)

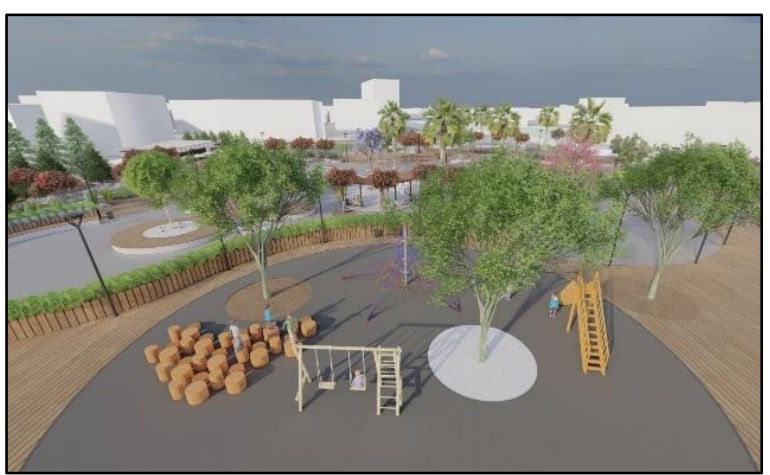

(b)

Şekil 6. (a) Yay şeklinde tasarlanan oturma birimi, (b) Çocuk oyun alanı

Meydanda, kaya bahçelerinde kullanılan yeşil renkli saç şeklindeki yapraklarıyla hafif rüzgârlarda bile salınarak rüzgârla bir ahenk oluşturması nedeniyle Stipa tenuissima ile kaya bahçelerinde ve kurak alanlarda yetişebilmesi nedeniyle Washingtonia filifera bitkisi kullanılmış altına dolomit taşı ve su isteği az olması nedeniyle Dianthus barbatus bitkisi kullanılmıştır. Akdeniz iklim koşullarına uyum sağlaması, su isteğinin orta olması ve gösterişli eflatun renkli çiçekleri nedeniyle Jacaranda mimosifolia korunmuştur. Doğal bitki türü olması ve çekici pembe çiçekleri nedeniyle Cercis siliquastrum bitkisi kullanılmış altına sukkulent, çekici formlu ve mavimsi-gri yapraklı Agave americana, kuraklığa toleranslı, mavi-yeşil yapraklı ve güzel formlu Festuca glauca 'Elijah Blue', Akdeniz iklim koşullarına uyumlu Cortaderia selloana

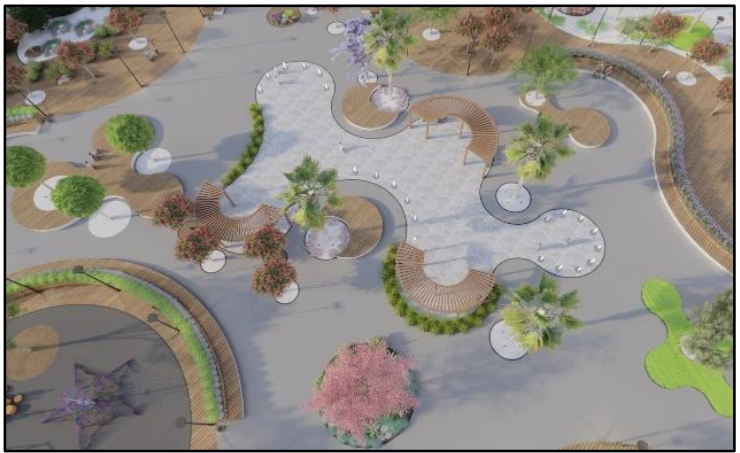

(a)
'Cool Ice', kaya bahçelerinde kullanılması ve Akdeniz İklim koşullarına uyumlu olması nedeniyle Phormium tenax bitkisi kompozisyonu yapılmış ve bitkilerin altına doğal çam kabuğu malçı kullanılmıştır (Şekil 7a).

Güneyde bulunan girişte kuraklığa dayanıklı az su isteyen bitki türleri kullanılmış bunlardan doğal türler arasında yer alan, kuraklığa dayanıklı Olea europaea vurgu yapmak amacıyla kullanılmış ve altına sukkulent karakterde ek bakıma intiyaç duymayan, Akdeniz Bölgesi'nin doğal bitki örtüsünde bulunan ve çim görünümü sağlaması amacıyla Sedum sediforme kullanılmıştır (Şekil 7b).

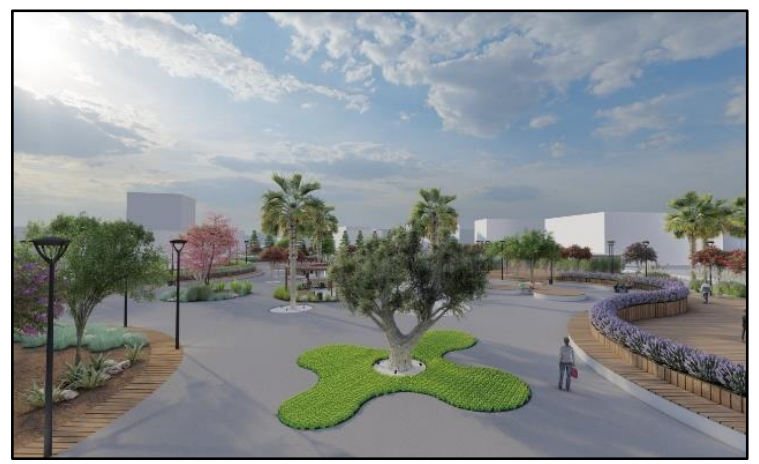

(b)

Şekil 7.(a) Meydan, (b) Girişte Olea europaea ve Sedum sediforme ile oluşturulan bölüm

Girişin batısında bulunan bitki parterinde doğal bitki türü olan Celtis australis altına çöl ve kaya bahçelerinde kullanılması ve su isteği az olması nedeniyle Buxus microphylla 'Japonica' kullanılmış ve altına dolomit taşı kullanılmıştır. Mevcutta bulunan Acacia sp. bitkisi kaya ve çöl bahçelerinde kullanılması, su isteğinin az olması ve Akdeniz iklim koşullarına uyum sağlaması nedeniyle korunmuştur. Aynı parterde doğal türlerden Vitex agnuscastus, çekici formlu ve mavimsi-gri yapraklı Agave americana L., doğal türler arasında yer alan, kuraklığa dayanıklı ve ek bakıma intiyaç duymayan aromatik yapraklı Rosmarinus officinalis, kuraklığa toleranslı Festuca glauca 'Elijah Blue', sarı turuncu çiçekli ve çekici yapraklı, sukkulent Aloe vera L. doğal taşlarla kompozisyon oluşturularak altında doğal çam kabuğu malçı kullanılmıştır (Şekil 8a). 
Girişin doğusunda yer alan 'S' şeklinde tasarlanan ahşap kaplama saksıda doğal türler arasında yer alan, kuraklığa dayanıklı ve ek bakıma intiyaç duymayan aromatik yapraklı Lavandula officinalis kullanılmıştır. Saksının

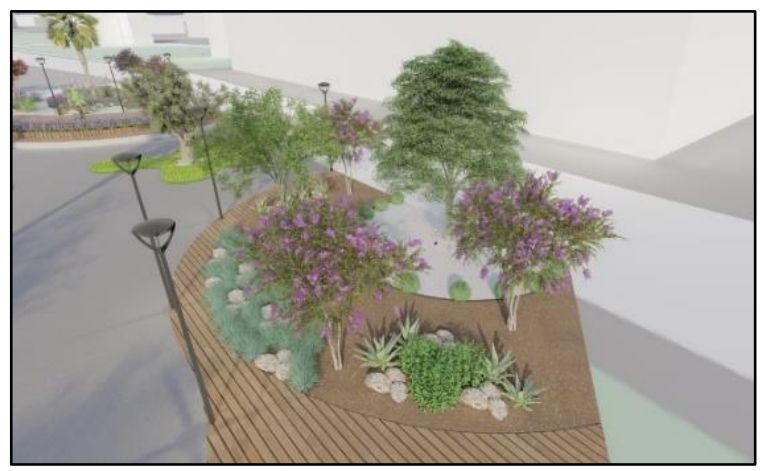

(a) doğusunda ahşap zemin üzerinde mevcutta bulunan $L a-$ gerstromia indica ve Acacia sp. yol ağaçlandırması amacıyla ve amorf yapılı oturma birimi saksısında mevcutta bulunan Acacia sp. kullanıcılara gölge sağlaması amacıyla korunmuştur (Şekil 8b).

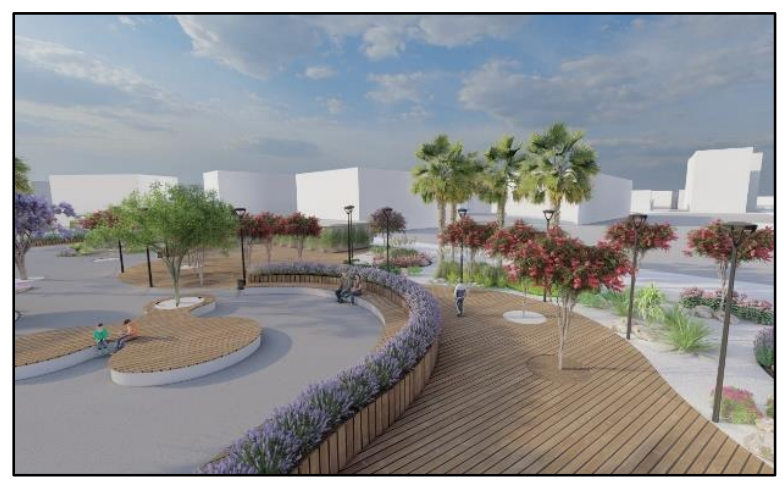

(b)

Şekil 8. (a) Girişin batısındaki bitki parteri, (b) Saksıda kullanılan Lavandula officinalis ve korunan Lagerstromia indica ile Acacia sp.

Alanın doğusunda yer alan bitki parterinde az su isteyen kuraklığa dayanıklı bitki türleri kullanılmıştır. Mevcutta bulunan Washingtonia sp. bitkileri korunmuştur. Doğal türlerden Vitex agnus-castus ve Rosmarinus officinalis, sukkulent Agave americana L, gösterişli kırmızı başak ve kırmızı yapraklara sahip Pennisetum setaceum 'Rubrum', Akdeniz iklim koşullarına uyumlu Cortaderia selloana 'Cool Ice' ve Bougainvillea glabra, küçük kırmızı meyveleri ile Cotoneaster horizontalis kuraklığa dayanıkı, çöl ve kaya bahçelerinde kullanılan, sukkulent Furcraea selloa 'Marginata' ve Echeveria secunda 'Glauca', ek bakıma ihtiyaç duymayan, Akdeniz Bölgesi'nin doğal bitki örtüsünde bulunan ve çim görünümü sağlaması amacıyla Sedum sediforme, gösterişli olan altın sarısı çiçekleri maviye çalan gri-yeşil yaprakları ile Euryops pectinatus, su isteğinin az olan Dracena indivisa, kuraklığa dayanıklı Dasylirion longissumum, çöl ve kaya bahçelerinde kullanılan Pyracantha coccinea 'Nana', Lantana camara ve Dodonea viscosa, doğal türler arasında yer alan, kuraklığa dayanıklı ve ek bakıma intiyaç duymayan aromatik yapraklı Lavandula stoechas bitkisi ile doğal taşlarla kompozisyon oluşturulmuş bitkilerin altında dolomit taşı ve doğal çam kabuğu malçı kullanılmıştır.

\section{“Kuralsız Park” Tasarım Proje Uygulama Maliyeti}

Kurakçıl peyzaj tasarım yaklaşımıyla tasarlanan "Kuralsız Park" peyzaj tasarım projesinin bitkisel tasarım paftasında kullanılması önerilen bitkilerin 2021 yılı Ocak ayına ait birim fiyatları fidanlıklardan temin edilmiştir. Elde edilen birim fiyat bilgisi doğrultusunda toplam maliyet hesaplanmıştır. Kullanılması planlanan bitkisel materyalin toplam maliyeti 31.860 €'dir (Tablo 1).

Kurakçıl peyzaj tasarım yaklaşımıyla tasalanan Kuralsız Park peyzaj projesinde kullanılması önerilen zemin kaplama, pergola, çit, malç çeşitleri, sulama sistemi gibi yapısal malzemelerin 2021 yılı Ocak ayına ait birim fiyatları ilgili firmalardan temin edilmiştir. Elde edilen birim fiyat bilgisi ile proje kapsamında kullanılması planlanan miktarlar çarpılarak toplam maliyet hesaplanmıştır. Kullanılması planlanan yapısal materyalin toplam maliyeti 678.575 も’dir (Tablo 2). 
Kent Parkına Yönelik Kurakçıl Peyzaj Tasarım Önerisi: Antalya Serdengeçti Parkı

Tablo 1. "Kuralsız Park" peyzaj tasarım projesinde kullanılan bitkisel materyalin maliyeti

\begin{tabular}{|c|c|c|c|}
\hline Bitki İsmi (Latince) & Adet & Birim Fiyat (も) & Toplam (も) \\
\hline Agapanthus orientalis & 12 & 20 も & 240 も \\
\hline Agave americana $L$. & 13 & 100 も & 1.300 も \\
\hline Aloe vera $L$. & 5 & 20 も & 100 も \\
\hline Bougainvillea glabra & 3 & 40 も & 120 も \\
\hline Buxus microphylla 'Japonica' & 11 & 80 も & 880 も \\
\hline Carex oshimensis 'Evergold' & 43 & 10 も & 430 も \\
\hline Casuarina aquisetifolia & 11 & 140 も & 1.540 も \\
\hline Celtis australis & 1 & 150 も & 150 も \\
\hline Cercis siliquastrum & 1 & 250 も & 250 も \\
\hline Cotoneaster horizontalis & 9 & $20 も$ & 180 も \\
\hline Cortaderia selloana 'Cool Ice' & 12 & 25 も & 300 も \\
\hline Cycas revoluta & 7 & 175 も & 1.225 も \\
\hline Cyperus alternifolius $L$. & 20 & 15 15 & 300 も \\
\hline Dasylirion longissumum & 3 & 1.000 も & 3.000 も \\
\hline Dianthus barbatus $L$. & 35 & $5 も$ & $175 も$ \\
\hline Dodonea viscosa & 2 & 15 も & 30 も \\
\hline Dracena indivisa & 2 & 90 も & 180 も \\
\hline Echeveria secunda 'Glauca' & 27 & 20 も & 540 も \\
\hline Euryops pectinatus & 5 & 10 も & 50 も \\
\hline Festuca glauca 'Elijah Blue' & 86 & $5 も$ & 430 も \\
\hline Furcraea selloa 'Marginata' & 5 & 85 も & 425 も \\
\hline Hedera helix & 8 & 25 も & 200 も \\
\hline Iris germanica L. & 50 & 15 も & 750 も \\
\hline Lantana camara $L$. & 6 & 15 15 & 90 も \\
\hline Laurus nobilis (tijli) & 3 & 220 も & 660 も \\
\hline Lavandula officinalis & 31 & 20 も & 620 も \\
\hline Lavandula stoechas & 63 & 20 も & 1,260 も \\
\hline Lagerstromia indica & 7 & 180 も & 1,260 も \\
\hline Lonicera etrusca & 22 & 50 も & 1,100 も \\
\hline Miscanthus sinensis 'Flamingo' & 12 & 45 も & 540 も \\
\hline Myrtus communis & 66 & 20 も & 1,320 も \\
\hline Olea europaea & 1 & 200 も & 200 も \\
\hline Pennisetum setaceum 'Rubrum' & 25 & 15 も & 375 も \\
\hline Phormium tenax & 5 & 115 も & 575 も \\
\hline Pyracantha coccinea 'Nana' & 10 & 20 も & 200 も \\
\hline Rosmarinus officinalis & 6 & 15 も & 90 も \\
\hline Salvia officinalis & 38 & 20 も & 760 も \\
\hline Santolina chamaecyparissus $L$. & 96 & 20 も & 1,920 も \\
\hline Sedum sediforme & $\begin{array}{l}63 \mathrm{~m}^{2} \\
(992)\end{array}$ & $5 も$ & 4,960 も \\
\hline Stipa tenuissima & 48 & 15 も & 720 も \\
\hline Vitex agnus-castus & 7 & 15 15 & $105 も$ \\
\hline Washingtonia filifera & 5 & 500 も & 2.500 も \\
\hline \multicolumn{2}{|c|}{ *2021 yılı Piyasa Rayiç fiyatlarıyla hazırlanmıştır. } & TOPLAM & *31.860も \\
\hline
\end{tabular}


Kent Parkına Yönelik Kurakçıl Peyzaj Tasarım Önerisi: Antalya Serdengeçti Parkı

Tablo 2. Kuralsız park peyzaj tasarım projesinde kullanılan yapısal malzemelerin maliyet hesapları

\begin{tabular}{|c|c|c|c|c|}
\hline Yapısal Malzemeler Listesi & Miktar & Boyut & Birim Fiyat & Toplam Fiyat \\
\hline Doğal Çam kabuğu & $432 \mathrm{~m}^{2}$ & $15-25 \mathrm{~mm}$ & $\begin{array}{l}265 \\
\text { €/m } \mathrm{m}^{3}+\mathrm{kdv}\end{array}$ & 6.754 も \\
\hline $\begin{array}{l}\text { Ahşap Deck Zemin- Kap- } \\
\text { lama }\end{array}$ & $\begin{array}{l}1.935 \\
\mathrm{~m}^{2}\end{array}$ & $15 \times 200 \times 5 \mathrm{~cm}$ & $85 も / \mathrm{m}^{2}+\mathrm{kdv}$ & 194.080 も \\
\hline Kumlamalı Granit & $315 \mathrm{~m}^{2}$ & $3 \times 30 \times 60 \mathrm{~cm}$ & $\begin{array}{l}95 \ddagger / \mathrm{m}^{2}+ \\
\mathrm{kdv}\end{array}$ & 35.311 も \\
\hline EPDM zemin kaplama & $266 \mathrm{~m}^{2}$ & $\begin{array}{l}10 \mathrm{~mm} s b r+7 \mathrm{~mm} \\
\text { epdm }\end{array}$ & 20 Euro/ $\mathrm{m}^{2}$ & 5.320 Euro/47.241も \\
\hline Dolomit taşı & $540 \mathrm{~m}^{2}$ & $60-100 \mathrm{~mm}$ & $\begin{array}{l}450 \\
\text { も/ton+kdv }\end{array}$ & $25.806 も$ \\
\hline Sentetik Reçineli Terrazzo & $\begin{array}{l}2.011 \\
m^{2}\end{array}$ & $8 \mathrm{~mm}$ & 15 Euro/m² & 30.165 Euro/267.865 も \\
\hline Metal Çit Sistem & 6 adet & $135 \mathrm{~m}^{2}$ & 266 も/m² & 36.000 も \\
\hline Pergola & 3 adet & $\begin{array}{l}\left(20 \mathrm{~m}^{2}\right) \times(\text { 3adet })=60 \\
\mathrm{~m}^{2}\end{array}$ & 10.000 も & $30.000 €$ \\
\hline Otomatik Sulama Sistemi & & & & $35.000 €$ \\
\hline \multicolumn{3}{|c|}{ *2021 yılı Piyasa Rayiç fiyatlarıyla hazırlanmıştır. } & TOPLAM & *678.575 も \\
\hline
\end{tabular}

\section{Tasarım Önerisi II: Mozaik Park}

Bu peyzaj tasarım projesinde kurakçıl peyzaj tasarımı yaklaşımıyla farklı konseptlerdeki bahçelerin bir arada kullanılmasıyla oluşturulan kompozisyona Mozaik park adı verilmiştir. Zen bahçesi, çöl bahçesi gibi farklı bölümleri olan parkın mozaik gibi bir yapı oluşturulması sağlanmıştır.

\section{Leke Plan Çalışması}

Çalışma alanında mevcut olan kafe, WC ve trafo haricindeki yapıların kaldırımasına karar verilmiştir. El emeği satış birimlerinin yerlerinin değiştirilmesine karar verilmiştir. Çocuk oyun alanının kafeye yakın olması amaçlanarak yerinin değiştirilmesine karar verilmiştir. Kurakçıl peyzaj uygulamasına uygun bir şekilde parkın içinde çeşitli kompozisyonlara sahip bahçelerin yapımına karar verilmiştir. Bunlar; Zen bahçesi ve Çöl bahçesidir.

Kullanım alanları belirlendikten sonra alanda ana aks ve bağlantı yolları belirlenmiştir. Sonrasında alanın kuzey ve güney bölgelerine ve bu bölgelerin gölge ve aydınlanma sürelerine göre bitkisel tasarımın adımları atılmış- tır. Antalya ilinin iklim koşulları da göz önünde bulundurularak alanın en kuzeyinde orta su isteği olan bitkiler ve güneye doğru az su isteği olan bitkiler konumlandırılmıştır (Şekil 9).

\section{Kesin Plan}

Peyzaj tasarımının leke plan çalışması aşamasında verilen kararlar doğrultusunda alan kullanımlarının yerleri ve formları kesinlik kazanmıştır. Kullanım alanlarının tasarımı, belirlenen yerlerde, ana aks ve bağlantı yolları ile çözülmüştü. Oturma birimleri olarak ahşap yay şeklindeki pergolalar kullanılmış olup bunlara ek satış birimlerinin bulunduğu alanda, blok ahşap oturma birimleri kullanıımıştır. Çocuk oyun alanı, leke plan çalışmasında karar verildiği gibi kafe binasına yakın tasarlanmıştır. Çeşitli kompozisyonlara sahip Zen Bahçesi ve Çöl Bahçesi tasarımları yan yana çözülmüştür. Bunun yanında Çocuk Oyun Alanı ile Kafe binası arasında da tasarımın formuna uygun bir zen bahçesi tasarlanmıştır. Yapısal döşemeler ve çeşitli malçlar kullanılarak yeşil alanlar azaltılmış olup kurakçıl peyzaj ilkeleri doğrultusunda bir çaışma yapıımıştır (Şekil 10). 
Kent Parkına Yönelik Kurakçıl Peyzaj Tasarım Önerisi: Antalya Serdengeçti Parkı

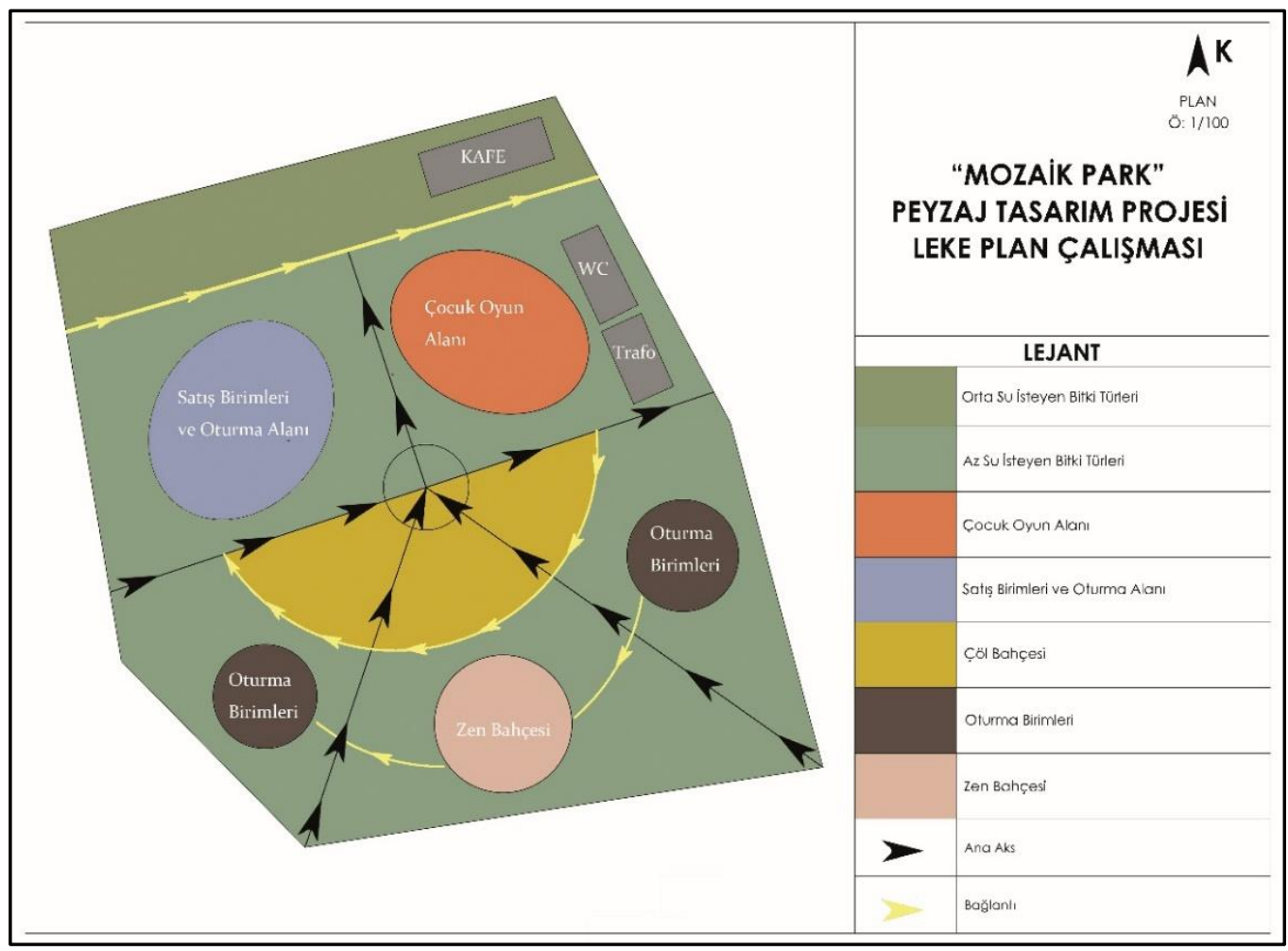

Şekil 9. Leke plan çalışması

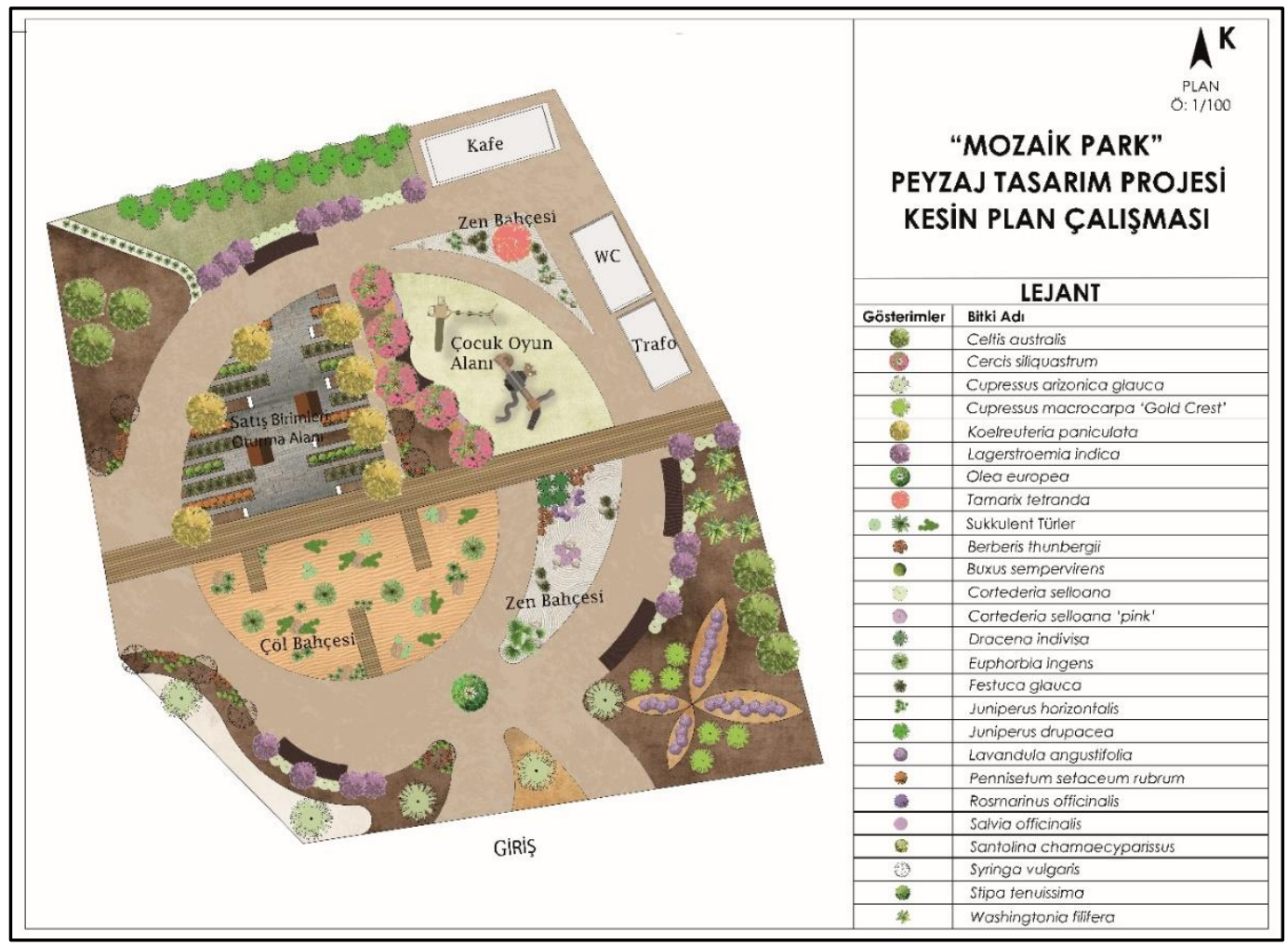

Şekil 10. Kesin plan çalışması 
Bitkisel tasarımına başlarken seçilen bitkilerin kurakçıl peyzaj yaklaşımına uygun türler olmasına özen gösterilmiştir. Antalya'nın doğal bitki örtüsüne ait bitki türleri ve bununla birlikte alanın toprak ve iklim yapısına uygun türler de seçilmiştir. Alanda mevcut bazı bitki türleri ilkelere ve alan tasarımına uygunluğu açısından korunmuştur. Bunlar; Juniperus drupacea, Laurus nobilis, Washingtonia filifera bitkileridir. Tasarımda doğal çam kabuğu ve dolomitin farklı renkleri ile malçlar uygulamaları önerilmiştir.

Girişte kullanılan Cupressus arizonica'ya sağ tarafta Cupressus macrocarpa ve Lavandula officinalis bitkileri ile malç üzerinde oluşturulan kompozisyon eşlik etmek- tedir (Şekil 10a). Alanın en doğusunda bulunan Washingtonia filifera bitkileri alanda mevcut olup korunmuştur. Bunlara ek olarak doğal bitki örtüsünde mevcut olan Celtis australis bitkisi sınırlayıcı olarak alanın doğu ve kuzeybatı bölgelerinde kullanılmıştır.

Alanda tasarlanan iki adet zen bahçesi bulunmaktadır. Girişte bulunan zen bahçesinde (Şekil 10b). Juniperus horizontalis, Festuca glauca, Salvia officinalis, Rosmarinus officinalis Berberis thunbergii, Cortaderia selloana "Pink Feather" ve Dracena indivisa kullanılmıştır. Boyutları değişen doğal taşlar ile birlikte oluşturulan kompozisyonda su isteği az olan ve doğal bitki örtüsünde yayııış gösteren bitki türleri kullanılmıştır.

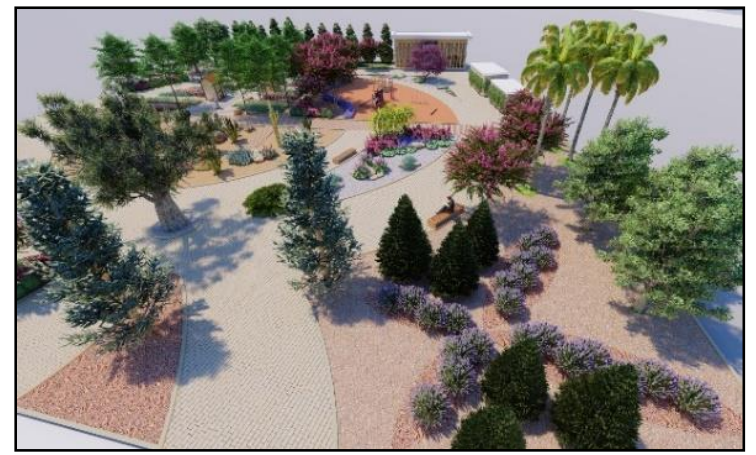

(a)

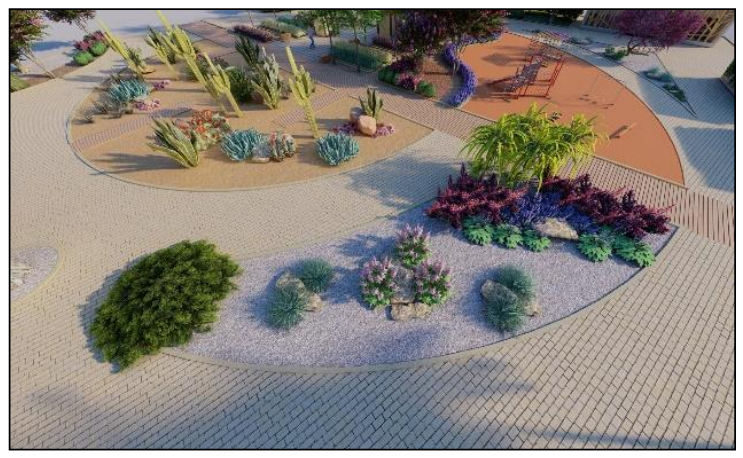

(b)

Şekil 10. (a) Giriş bölümü, (b) Zen bahçesi

Alanın merkezinde tasarlanan çöl bahçesi suyun az kullanımına vurgu yapılması amacıyla kaktüs ve sukkulent bitki türleri kullanılmıştır (Şekil 11a). Bakım isteği ve su isteği az olan bu bitkiler; Aloe vera, Opuntia ficus indica, Mamillaria sp. Agave americana, Euphorbia ingens, Echeveria sp., Sempervivum sp., kurakçıl peyzaj tasarımının çöl bahçesi konseptinde doğal taşlar ile yer almışlardir.

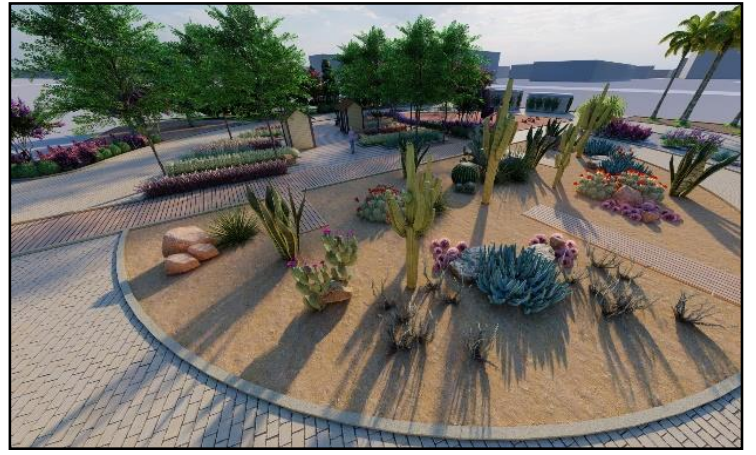

(a)
Çocuk oyun alanında yapılan bitkilendirme tasarımında Cercis siliquastrum, Salvia officinalis ve Buxus sempervirens kullanılmıştır. Su isteği az ve alanın ekolojik özelliklerine uygun olması özelliklerinden dolayı bu bitkiler ile kompozisyon oluşturulmuştur (Şekil 11b). Farklı renkte çam kabuğu malçlar kullanıımıştır.

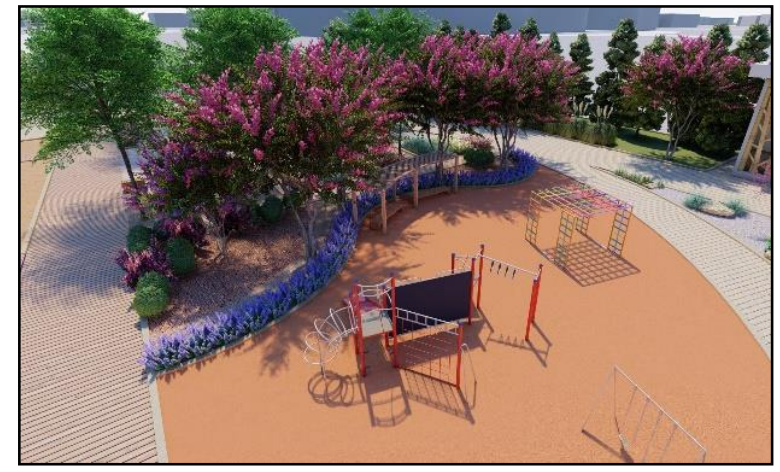

(b)

Şekil 11. (a) Çöl bahçesi, (b) Çocuk oyun alanı 
Alanın en kuzeyinde kullanılan bitkiler arasında alanda mevcut bulunan ve korunması tercih edilen Juniperus drupacea, Laurus nobilis bitkilerinin yanında Lagerstroemia indica ve Cortaderia selloana bitkisi kullanılmıştır (Şekil 12). Alanda üç yer örtücü bitki türü kullanıımıştır. En batıda çam kabuğu malç kullanılmıştır. Kafe yanında ise bakım isteği ve su tüketimi az olan Sedum sediforme

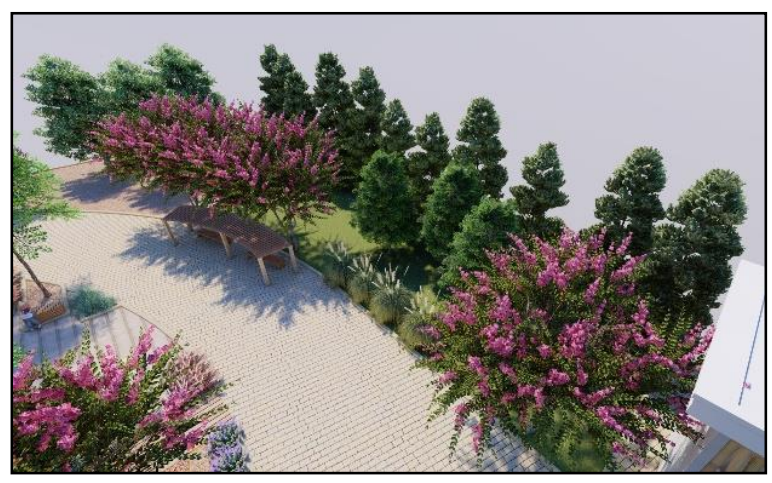

(a) ile çim görünümü oluşturulmuştur. Malç ile yeşil alan birbirinden dolomit taşları ile ayrılmış bu kısımda da Sempervivum sp. türü kullanılmıştır. WC ve trafo binalarının cepheleri ahşap çit ile kaplanmış ve ahşap çit üzerine Jasminum officinale kullanılarak estetik ve alana uyumlu bir biçimde beton görünümü ortadan kaldırılmıştır (Şekil 12b).

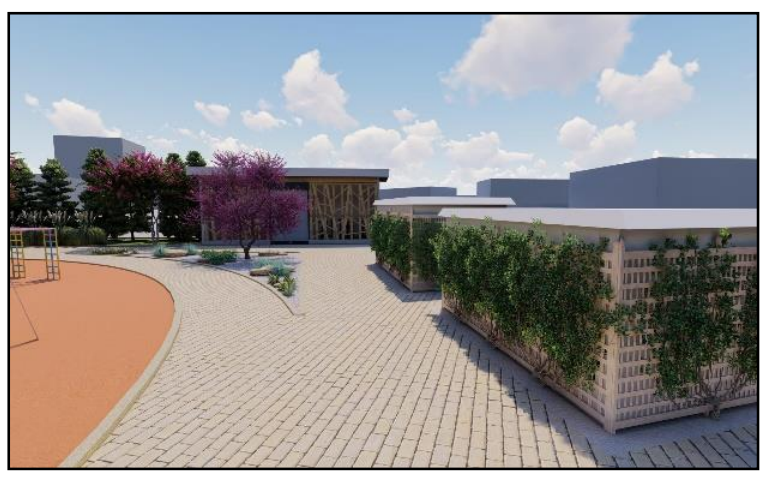

(b)

Şekil 12. (a) Alanın kuzeyinde yer alan kafe yanı bitkilendirme tasarımı, (b) WC ve trafo ahşap çit ile bitkilendirme

\section{“Mozaik Park” Tasarım Proje Uygulama Maliyeti}

Kurakçıl peyzaj tasarım yaklaşımıyla tasalanan Mozaik Park peyzaj tasarım projesinin bitkisel tasarım paftasında kullanılması önerilen bitkilerin 2021 yılı Ocak ayına ait birim fiyatları fidanlıklardan temin edilmiştir. Elde edilen birim fiyat bilgisi ile adetler çarpılarak toplam maliyet hesaplanmıştır. Kullanılması planlanan bitkisel materyalin toplam maliyeti 32.325 も’dir (Tablo 3).

Tablo 3. "Mozaik Park" peyzaj tasarım projesinde kullanılan bitkisel materyalin maliyeti

\begin{tabular}{|c|c|c|c|}
\hline Bitki ismi (Latince) & Adet & $\begin{array}{l}\text { Birim fiyat } \\
\text { (も) }\end{array}$ & Toplam (も) \\
\hline Celtis australis & 6 & 150 も & 900 も \\
\hline Cercis siliquastrum & 5 & 250 も & 1.250 も \\
\hline Cupressus arizonica & 5 & 150 も & 750 も \\
\hline Cupressus macrocarpa & 6 & 150 も & 900 も \\
\hline Koelreuteria paniculata & 7 & 280 も & 1.960 も \\
\hline Lagerstroemia indica & 15 & 180 も & 2.700 も \\
\hline Olea europea & 1 & 200 も & 200 も \\
\hline Tamarix tetranda & 1 & 80 も & 80 も \\
\hline Agave americana & 7 & 100 も & 700 も \\
\hline Berberis thunbergii 'nana' & 10 & 15 も & 150 も \\
\hline Berberis thunbergii & 33 & 20 も & 660 も \\
\hline Buxus sempervirens & 30 & 80 も & 2.400 も \\
\hline Cortederia selloana 'pink' & 3 & 20 も & 60 も \\
\hline Cortederia selloana & 22 & 20 も & 440 も \\
\hline Dracena indivisa & 3 & 90 も & 270 も \\
\hline Euphorbia ingens & 2 & 780 も & 1.560 も \\
\hline Echeveria elegans & 8 & 20 も & 160 も \\
\hline Festuca glauca & 100 & 5 5 & 500 も \\
\hline Juniperus horizontalis & 3 & $55 も$ & 165 も \\
\hline Jasminum officinale & 4 & $35 も$ & 140 も \\
\hline Lavandula angustifolia & 32 & 20 も & 640 も \\
\hline Mammilaria sp & 7 & $28 も$ & 196 も \\
\hline Opuntia ficus indica & 6 & 20 も & 120 も \\
\hline
\end{tabular}


Kent Parkına Yönelik Kurakçıl Peyzaj Tasarım Önerisi: Antalya Serdengeçti Parkı

\begin{tabular}{|c|c|c|c|}
\hline Pennisetum setaceum rubrum & 68 & 15 も & 1.020 も \\
\hline Rosmarinus officinalis & 55 & $15 も$ & 825 も \\
\hline Salvia officinalis & 7 & 20 も & 140 も \\
\hline Santolina chamaecyparissus & 4 & 20 も & 80 も \\
\hline Sedum sediforme & $150 m^{2}$ & 5 も & 12.000 も \\
\hline Sempervivum sp. & 25 & 10 も & 250 も \\
\hline Syringa vulgaris & 8 & $85 も$ & 680 も \\
\hline Stipa tenuissima & 55 & $15 も$ & 825 も \\
\hline \multicolumn{2}{|c|}{ *2021 yılı Piyasa Rayiç fiyatlarıyla hazırlanmıştır. } & Toplam & *32.325 \\
\hline
\end{tabular}

Kurakçıl peyzaj tasarım yaklaşımıyla tasalanan Mozaik park peyzaj tasarım projesinde kullanılması önerilen zemin kaplama, pergola, çit sistemi, malç çeşitleri, sulama sistemi gibi yapısal malzemelerin 2021 yılı Ocak ayına ait birim fiyatları ilgili firmalardan temin edilmiştir. Elde edilen birim fiyat bilgisi ile proje kapsamında kullanıması planlanan miktarlar çarpılarak toplam maliyet hesaplanmıştır. Kullanılması planlanan yapısal materyalin toplam maliyeti 288.368 も’dir (Tablo 4).

Tablo 4. Mozaik park peyzaj tasarım projesinde kullanılan yapısal malzemelerin maliyet hesapları

\begin{tabular}{|c|c|c|c|c|}
\hline $\begin{array}{l}\text { Yapısal Malzemeler Lis- } \\
\text { tesi }\end{array}$ & Miktar & Boyut & Birim Fiyat & $\begin{array}{l}\text { Toplam } \\
\text { Fiyat }\end{array}$ \\
\hline Doğal Çam kabuğu & $750 \mathrm{~m}^{2}$ & $15-25 \mathrm{~mm}$ & $265 も / m^{3}+k d v$ & $10.900 €$ \\
\hline $\begin{array}{l}\text { Ahşap Deck Zemin- } \\
\text { Kaplama }\end{array}$ & $400 \mathrm{~m}^{2}$ & $15 \times 200 \times 5 \mathrm{~cm}$ & 85 も/m² $+k d v$ & $31.025 も$ \\
\hline Doğal Granit Taş Plak & $250 \mathrm{~m}^{2}$ & $4 \times 50 \times 75 \mathrm{~cm}$ & $95 € / m^{2}+k d v$ & 23.750 も \\
\hline Andezit Mozaik Parke & $270 \mathrm{~m}^{2}$ & $11 \times 20 \times 11 \mathrm{~cm}$ & $90 € / m^{2}+k d v$ & 24.300 も \\
\hline EPDM zemin kaplama & $290 \mathrm{~m}^{2}$ & $\begin{array}{l}10 \mathrm{~mm} \text { sbr }+7 \mathrm{~mm} \\
\text { epdm }\end{array}$ & 20 Euro/ $\mathrm{m}^{2}$ & $\begin{array}{l}5800,00 \\
\text { Euro/ } \\
\mathbf{5 1 . 5 0 3} \boldsymbol{t}\end{array}$ \\
\hline Dolomit taşı & $750 \mathrm{~m}^{2}$ & $2-4 \mathrm{~cm}$ & $\begin{array}{l}350 \\
\text { も/ton+kdv }\end{array}$ & $25.000 €$ \\
\hline Ahşap Çit Sistem & 6 adet & $155 m^{2}$ & $238 も, / \mathrm{m}^{2}$ & 36.890 も \\
\hline Pergola & 6 adet & $\begin{array}{l}\left(20 \mathrm{~m}^{2}\right) \times(\text { 5adet })=100 \\
\mathrm{~m}^{2}\end{array}$ & 10.000 も & $50.000 €$ \\
\hline $\begin{array}{l}\text { Otomatik Sulama Sis- } \\
\text { temi }\end{array}$ & & & & 35.000 も \\
\hline \multicolumn{3}{|c|}{ *2021 yılı Piyasa Rayiç fiyatlarıyla hazırlanmıştır. } & TOPLAM & *288.368も \\
\hline
\end{tabular}

\section{SONUÇLAR}

Kentleşmeyle birlikte doğal alanların giderek azalması ve küresel ısınmaya bağlı olarak oluşan iklim değişikliğinden kaynaklanan kuraklığın etkileri gün geçtikçe insan yaşamını daha da zor hale getirmektedir. Ekolojik temele dayanmayan kentsel planlama ve tasarım anlayışları özellikle büyük kentlerde yaşamı giderek zorlaştırmaktadır.

Ülkemizdeki peyzaj tasarım çalışmalarında ekolojik yaklaşımdan önce ekonomik ve estetik tasarımlar dikkate alınmaktadır. Bunun sonucu, ekolojik ve iklimsel koşullara uygun olmayan, doğal yapıyla bağdaşmayan, bakım masrafları fazla, sürdürülebilir nitelikte olmayan yapısal ve bitkisel malzeme kullanımlarına dayanan görsel tasarımlar ortaya çıkmaktadır.

Başta peyzaj mimarlığı olmak üzere kentsel tasarım ile ilgilenen tüm meslek disiplinlerinin sürdürülebilir tasarım ilkelerini benimsemesi, doğal kaynakların korunmasını temel prensip olarak kabul ederek koruma-kullanma dengesiyle hareket etmelidir. Bu bilinçle tasarlanan doğaya saygılı sürdürülebilir yeşil alanlar kullanıcılar tarafından daha fazla beğenileceği öngörülmektedir.

Su kaynaklarının korunması adına suyun yoğun olarak kullanıldığı peyzaj mimarlığı çalışmalarında estetik kaygıdan uzaklaşarak doğa ve çevre ile uyumlu, natüralist ve alternatif yaklaşımlar tercih edilmelidir. Bu yaklaşımlardan biri kurakçıl peyzaj tasarım anlayışıdır. Kurakçıl peyzaj uygulamalarında doğal bitki türlerin kullanımı suyun daha etkin kullanılması açısından oldukça önemlidir. Çalışma kapsamında önerilen iki peyzaj tasarımı ile özellikle suyun etkin kullanımı teşvik edilmiş ve az su isteyen bitkilerin kullanımı ile oluşturulan peyzaj yaklaşımlarının önemi vurgulanmıştır.

Küresel ısınma ve iklim değişikliğinin de etkisiyle ülkemiz özelinde kullanılabilir su kaynaklarının arzu edilen 
seviyede olmaması, barajlardaki doluluk oranlarının yıldan yıla azalması, kurakçıl peyzaj tasarımının bu çaIışma kapsamında önemini ortaya koymuştur. Bunun yanında, kent merkezlerinde yer alan ve tüm kente hizmet eden parkın, tematik olarak tasarlanmasının, kullanıcılar üzerinde çevresel farkındalık oluşturacağı, çevre bilincini geliştireceği, doğal kaynaklarının önemine dikkat çekeceği öngörülmüştür.

Kurakçıl peyzaj tasarımı anlayışı ile hazırlanan projelerin diğer peyzaj tasarım projelerine göre avantajı, daha az bakım ve su isteyen bitkisel materyalin kullanılması ve ekonomik olmasıdır. En önemli dezavantajı ise sınırlı sayıda bitki materyalinin kullanılabilmesi ve buna bağlı olarak renk, doku, form gibi bitkisel tasarım öğeleri açısından çeşitlilik oluşturamamasıdır. Avantaj ve dezavantajları yanında tasarlanan projelerin en önemli çıktısı, özellikle kent merkezlerinde su kullanımının önemine dikkat çeken tematik parkların oluşturulmasıdır.

\section{KAYNAKLAR}

Aklanoğlu, F. (2009). Geleneksel yerleşmelerin sürdürülebilirliği ve ekolojik tasarım: Konya- Sille Örneği. Doktora Tezi, Ankara Üniversitesi.

Birişçi, T., Mansuroğlu, S., Söğüt, Z., Kalaycı Önaç, A., Dağ, V. (2017). Doğa dostu peyzaj uygulamaları. International Conference on Agriculture, Forest, Food Sciences and Technologies, Kapadokya.
Çorbacı, Ö.L., Özyavuz, M., Yazgan, M.E. (2019). Peyzaj mimarlığında suyun akıllı kullanımı: Xeriscape. International Journal of Agricultural and Natural Sciences, 4(1): 25-31.

Detweiler, A. J., Griffiths, P., Olson, R., Idea, E. (2005). An introduction to xeriscaping in the high desert and pictorial plant guide for Central and Eastern Oregon. https://cascadegardencenter.com/wp-content/uploads/2016/05/An-Introduction-to-Xeriscaping.pdf

Eroğlu, E., Acar, C. (2009). Trabzon ve yakın çevresi bazı yayla alanlarındaki Alpin bitkiler ve peyzaj mimarlığı çalışmalarında kullanım potansiyelleri. Düzce Üniversitesi Orman Fakültesi Ormancılık Dergisi, 5 (1): 42-59.

Keleş, R. (1998). Kentbilim Terimleri Sözlüğü, İmge Kitabevi, Ankara.

Korkut, A., Kiper, T., Topal, Ü.T. (2017). Kentsel peyzaj tasarımda ekolojik yaklaşımlar. Artium Dergisi, 5(1):14-26.

McHarg, I. (1969). Design with Nature. The Natural History Press, Garden City, New York.

Metin, M.Z., Koçan, N. (2020). Ankara Etimesgut Yıldırım Beyazıt Parkı Örneğinde Kurakçıl Peyzaj Tasarım Uygulaması. Mehmet Akif Ersoy Üniversitesi Fen Bilimleri Enstitüsü Dergisi, 11(Ek 1): 313-323.

Şahin, N. (2013). Kurakçıl peyzaj düzenlemesinde suyun etkin ve akılcı kullanımı-Xeriscape. Yüksek Lisans Tezi, Muğla Sıtkı Koçman Üniversitesi, Muğla, 65 s.

Wade, G.L., Midcap, J.T. (2007). A guide to developing a water-wise landscape. Xeriscape.

Welsh, D.F. (2000). Xeriscape North Carolina. National Zeriscape Council, USA, 28 pg.

Welsh, D.F., Welch, W.C. (2007). Xeriscape, Landscape Water Conservation.

Wilson, C., Feucht, J.R. (2007). Xeriscaping: creative landscaping, Colorado State University (no:7.228), USA. 